\title{
Improving Roma participation in European early childhood education systems through cultural brokering
}

Sarah Klaus (D) and Iram Siraj (D)

\section{How to cite this article}

Klaus, S. and Siraj, I. (2020) 'Improving Roma participation in European early childhood education systems through cultural brokering'. London Review of Education, 18 (1): 50-64. https://doi.org/10.18546/LRE.18.1.04

Submission date: 8 May 2019

Acceptance date: 4 October 2019

Publication date: 1 March 2020

\section{Peer review}

This article has been peer reviewed through the journal's standard double-blind peer review, where both the reviewers and authors are anonymized during review.

\section{Copyright}

(C) Copyright 2020 Klaus and Siraj. This is an Open Access article distributed under the terms of the Creative Commons Attribution Licence (CC BY) 4.0 https://creativecommons.org/licenses/by/4.0/, which permits unrestricted use, distribution and reproduction in any medium, provided the original author and source are credited.

\section{Open access}

London Review of Education is a peer-reviewed open-access journal. 


\title{
Improving Roma participation in European early childhood education systems through cultural brokering
}

\author{
Sarah Klaus* - Open Society Foundations, UK \\ Iram Siraj - University of Oxford, UK
}

\begin{abstract}
The Roma are Europe's largest minority ethnic group, yet too few Roma achieve a level of education that enables them to secure employment or positive life chances. Gaps in their attainment compared to other ethnic groups start to appear in the earliest years, with Roma participating in early education at half the rate of their peers. The European Commission has established expectations to increase participation rates, but change is painfully slow. Institutionalized discrimination and poverty underpin many structural factors, such as shortages of preschool places and unaffordable fees and costs, that are in a large part responsible for the low participation of Roma in early education. Yet multiple reports highlight cultural barriers as an additional significant challenge for Roma families, and recommend employing Roma as teaching assistants to bridge cultural differences. This article presents evidence from two qualitative studies that explore the impact of employing Roma in early childhood settings. The first, a survey conducted in the 21 European countries with the largest Roma populations, establishes current hiring trends and motivations for hiring Roma early childhood education staff, and estimates that at least 40,000 additional Roma staff are needed to ensure their proportionate representation in the workforce. The second uses case study methodology to capture learning from Serbia and the UK, where introducing Roma assistants is helping to bridge cultural barriers to Roma participation in early education. The article concludes with the observation that the social inclusion of Roma will also require interventions that start well before children enter formal education.
\end{abstract}

Keywords: Roma, early education, teaching assistants, cultural brokers, Europe

\section{Introduction}

Europe's education systems are largely failing Roma children. Stark differences in participation rates emerge in the earliest years, with Roma children participating in early education at half the rate of their peers (Brüggemann, 2012). These early differences set the stage for inequality in later life. Participation in quality early childhood education (ECE) helps the most disadvantaged children to gain some ground, bringing them closer to the developmental level of their more advantaged peers (Heckman et al., 2010; La Paro and Pianta, 2000; Schweinhart et al., 2005; Sylva et al., 2010; Sylva et al., 2008). The reverse, however, is also true: when systems prioritize the most advantaged children, the most disadvantaged children fall even further behind. Increasing Roma 
participation in early education becomes, therefore, essential to the broader European mission of full Roma integration.

This article delves deeper into the reasons for low participation of Roma children in ECE. It begins with a description of the context in which the majority of young Roma children are being raised, including discussion of the structural (access) barriers to preschool attendance. The focus of this article, though, is on less tangible, but extremely important, cultural barriers, which have been identified in multiple reports. Evidence from a multi-country survey is presented that illustrates the important role that the Roma ECE workforce plays in overcoming cultural barriers - through building trust with parents and communities, by improving communication, and by enriching the cultural competence of ECE settings. Examples from case studies conducted in Serbia and the UK are then used to demonstrate the positive role that Roma educators play in socially inclusive ECE classrooms. The article suggests that achieving equal rates of participation will require employing more Roma staff in preschools as a necessary additional measure.

\section{Young Roma children in Europe and their participation in preschool education}

The term 'Roma' is used collectively across Europe, and in this article, to refer to Roma, Sinti, Kale and related groups in Europe, including Travellers and people who identify themselves as 'Gypsies' in the UK. Roma collectively make up the largest minority group and are among the most disadvantaged citizens in Europe. The most widely accepted estimates from the Council of Europe (CoE) indicate that there are approximately 10-12 million Roma living in Europe, and that approximately half are citizens of the European Union (CoE, 2012).

The exclusion and deprivation experienced by Roma populations in Europe has been well-documented by the European Union Agency for Fundamental Rights (FRA) through three household surveys, the most recent in 2016. As a demographic group, Roma are one of the youngest populations in Europe; although all socio-economic levels are represented across the community, over 80 per cent live in households that fall below national poverty lines. A substantial number live in unsuitable housing in isolated settlements or poor neighbourhoods - often without access to basic utilities. Fewer than 33 per cent of Roma are in paid employment, and around 50 per cent indicate that they have faced discrimination in the past year. Access to maternal-child healthcare is lower for Roma in many countries, and malnutrition is high - leading to larger numbers of low birth-weight babies, higher infant mortality and higher rates of stunting. Vaccination rates are also substantially lower for Roma children across the European Union. And fewer than 20 per cent complete secondary or vocational school - the level generally required by most employers (Brüggemann, 2012; FRA, 2016; FRA and UNDP, 2012; Fundación Secretariado Gitano, 2009).

The European Commission has established targets for early education, and has urged member states to expand access to early education for Roma children prior to entry into formal primary education (European Commission, 2011, 2013a, 2013b). Rates of Roma participation in ECE vary dramatically across Europe. In Bosnia and Herzegovina, Republic of North Macedonia, and Montenegro, three countries with ECE coverage rates between 13 and 26 per cent, a 2011 UNDP/World Bank/European Commission survey found no statistically significant differences in participation rates of Roma and non-Roma children. That is, where ECE participation rates are very low 
for the majority population, they are correspondingly low for the Roma population (FRA and UNDP, 2012). The most recent European Union Minorities and Discrimination survey documents increases in Roma participation in ECE between 2011 and 2016, yet a stark gap between participation of Roma and non-Roma persists in most countries, with Roma children still participating on average at half the rates of non-Roma children. Only Hungary and Spain have come close to achieving the European Commission targets for Roma children, largely by making preschool compulsory and eliminating fees (FRA, 2016).

Taken together, these statistics establish that a majority of young Roma children grow up in extremely impoverished households with intolerable living conditions, headed by caregivers with low education and low employment levels. One Serbian parent in Serbia we interviewed while collecting research for the case study summarized later in this article described her situation:

We can't teach our kids, because we can't read, we can't write. And that's hard for us. We have so many children, we can't get books, footwear. Books, pencils, notebooks, we can't afford them. We can barely feed the kids, let alone buy shoes and provide everything. The child has to go clean and our kids go dirty. At least our children have to finish school. Half of our community is in jail, because they haven't finished school, they don't work.

Low social status has been found to exacerbate health inequality (Marmot, 2010), which impacts children's health and development (Irwin et al., 2007). Discrimination further impedes young Roma children's participation in education. In 2007, the European Court of Human Rights found the government of Czech Republic guilty of violating the rights of Roma children, who had been mis-assigned to special schools for children with intellectual difficulties based on inappropriate testing. Even when Roma children are not placed in special education, they are often provided poorer quality education in classrooms that are largely segregated to satisfy non-Roma parents, or in schools located near ghettoized settlements and communities (Chireac and Arbona, 2016).

Institutionalized inequalities manifest as practical barriers in ECE. Where there are shortages of preschool places (for instance, Slovakia), working parents are often prioritized, which excludes many Roma children (Vančíková et al., 2017). Unsurprisingly, a World Bank/UNDP/EC household survey in five countries found that access issues (such as availability of preschool places, transportation and fees) and hidden costs (such as clothing) remain the main barriers to Roma participation in ECE. Interestingly, the survey also identified cultural barriers as highly significant for many Roma parents. Between 25 per cent and 50 per cent of Roma parents - who participated in the survey and who do not send their children to preschool - would consider enrolling their children in preschool if a Roma person was on the staff. Similar percentages of parents not sending their children to preschool indicated that they thought their child was too young to go to preschool or that there is no need to send their child to preschool if care is available at home (World Bank, 2012).

Multi-country reports and guides on Roma ECE (Bennett, 2012; UNESCO and CoE, 2014; World Bank, 2012) consistently identify cultural barriers, such as those described above, as contributory factors to low Roma participation in ECE. All recommend introducing Roma teaching assistants or mediators to bridge cultural differences and support communication. The World Bank report cited above recommends removing cost barriers and introducing subsidies, informing parents of the benefits of preschool, reaching out to parents by introducing more Roma teaching assistants and supporting 
parenting at home. Echoing the 2012 World Bank report, UNESCO and the CoE (2014: 43) assert:

The official recognition of Roma assistants has been one of the success stories of Roma education in recent years, paralleled in the health sector by the employment of Roma health mediators. In most instances, these assistants have been effective bridges between Roma families and the school and have been instrumental in increasing the enrolment of Roma children and their retention in the education system ... In sum, a fast-track approach to increase the number of Roma assistants and to promote through further training, promising candidates to teacher status would be a welcome policy initiative.

Although there have been numerous initiatives to hire Roma teaching assistants in early education settings to improve participation of Roma children, there are few descriptive or impact studies. The two studies presented in this article contribute to this evidence base.

\section{Theoretical framework}

\section{Cultural brokering}

Hiring Roma staff in ECE settings to address cultural gaps is an example of a broader phenomenon, an intentional strategy to overcome cultural barriers: cultural brokering. Cultural brokering is concerned with the exchange and acquisition of social and cultural capital, through sharing knowledge and information across different communities, facilitating communication and engaging in problem solving, mediation, role modelling and advocacy. It is a term that was introduced by anthropologists, and describes the role of brokers and negotiators who provided linkages between colonial governments and the societies over which they ruled. Their roles included providing simple translation, interpreting cultural concepts, serving as buffers, mediating disputes and facilitating commercial relationships (Jezewski, 1995). This approach has broadened over the years, and has been adopted intentionally in diverse services (for example, healthcare, disability, mental health, business, education and child welfare) as governments seek to provide services to indigenous or new migrant populations.

Although accounts from the 1970s onwards describe the cultural brokering roles that native teachers, children and parents play in education systems (MartinezCosio and lannacone, 2007; Phillips and Crowell, 1994; Wyatt, 1978), the concept is substantially less developed in the literature. The positive impact of cultural brokers in education derives from their role in helping young children and families from diverse backgrounds to access a range of external assets. These include both the cultural capital that is acquired by children through their education in preschools and schools, and the social capital (or personal relationships and networks) that link both children and families with new resources and that widen social and economic opportunity.

Putnam (2000) distinguishes between two types of social capital: 'bonding' and 'bridging'. Bonding within a high-affinity group reinforces homogeneity and a common identity, thus perpetuating ethnic and class stratifications in society. In contrast, bridging links members from diverse groups to a range of external assets, widening social and economic opportunity and reducing inequality. Bridging promotes heterogeneity and identification with wider society. In school and 
preschool settings, children and their families interact, by necessity, with one another and school staff at a variety of levels - creating new social linkages, many of which transcend the school setting through friendships and diverse communal activities. Roma staff in preschools can serve in this important bridging function, catalysing the development of these new relationships.

\section{Cultural brokering and Roma education}

Most positions dedicated to Roma in education settings are titled either teacher assistant or mediator. Teacher assistant positions emphasize pedagogy and direct work with children and teachers, while mediator positions stress community engagement, document gathering and conflict resolution. However, they share a focus on improving access to education, reducing drop-out rates, improving academic achievement and fighting discrimination (Duvnjak et al., 2010). Assistants have the potential to pay attention to issues that are not covered by teachers; for example, providing additional support to children, engaging in deeper communication with families, providing conflict resolution and developing inter-agency connections. Typically, schools appreciate this additional support.

This article provides an overview of Roma staff in ECE in Europe, and focuses on the role of teacher assistants in Serbia and the UK. Assistants play an increasingly significant role in ECE. The latest research indicates that assistants make up as much as 50 per cent of ECE staff in some countries, including the UK. Yet they continue to remain largely invisible in statistics, with little data collected about their ethnicity, and few opportunities available for their professional advancement (Peeters et al., 2016). Peeters et al., (Peeters et al., 2018) describe three main roles attributed to assistants: a teaching role, a caring role and a bridging role. Roma assistants have been introduced with this third role in mind.

The explicit hiring of Roma staff into educational settings in Europe dates back to (at least) the 1980s, with very early pilots documented in Italy and Spain and, since then, it has been attempted in at least 26 countries (Liégeois, 2013; Rus, 2006). In many cases, NGOs were the first to introduce Roma mediators or teacher assistants (Demeuse et al., 2012). Only in some cases were new salaries absorbed into the budgets of local or national governments (Rus, 2006), and, even when local governments absorbed the costs of these positions, they remained contract-based and low paying - with thin job descriptions specific to each context. Relatively few countries have adopted the strategy at a national level - Serbia being the one that stands out.

Difficulties, however, can arise when Roma staff are perceived as being too close to either the school or the community (Rus, 2006). Schools may rely too heavily on Roma staff to work with Roma children, and non-Roma teachers can fail to build strong relationships with Roma parents. Furthermore, although some Roma mediator and teaching assistant positions were created to empower Roma and promote better educational outcomes for the community, in some cases, Roma who qualified as teachers found that they were able only to secure low-paying, para-professional positions (Demeuse et al., 2012).

\section{Studying Roma ECE workforce - methods}

This article draws evidence from two separate, but linked, studies (see Table 1) which explore the impact of hiring Roma into the ECE workforce. 
Table 1: Studies of the impact of hiring Roma into the ECE workforce

\begin{tabular}{|c|c|c|}
\hline Title & Description & Countries \\
\hline $\begin{array}{l}\text { 1. Straggling Behind: } \\
\text { Participation of Roma } \\
\text { Children and Employment } \\
\text { of Roma Staff in Early } \\
\text { Childhood Education in } \\
\text { Europe (2013-14) }\end{array}$ & $\begin{array}{l}\text { Survey of experts in } \\
21 \text { countries with the highest } \\
\text { Roma populations to document } \\
\text { extent of the Roma workforce in } \\
\text { ECE and understand trends and } \\
\text { motivations driving expansion } \\
\text { of the practice }\end{array}$ & $\begin{array}{l}\text { Albania, Bosnia, Bulgaria, } \\
\text { Croatia, Czech Republic, } \\
\text { Greece, Hungary, Ireland, } \\
\text { Italy, Kosovo, Macedonia, } \\
\text { Romania, Serbia, Slovakia, } \\
\text { Spain, Sweden, Turkey, UK }\end{array}$ \\
\hline $\begin{array}{l}\text { 2. Using Cultural Brokering } \\
\text { Strategies to Improve } \\
\text { the Early Education of } \\
\text { Roma, Gypsy and Traveller } \\
\text { Children: Case Studies from } \\
\text { the UK and Serbia (2015-18) }\end{array}$ & $\begin{array}{l}\text { Two qualitative case studies, } \\
\text { which focus on the cultural } \\
\text { brokering strategies used in } \\
\text { ECE settings to support Roma } \\
\text { participation }\end{array}$ & Serbia, UK \\
\hline
\end{tabular}

The first study, Straggling Behind: Participation of Roma Children and Employment of Roma Staff in Early Childhood Education in Europe, was a survey conducted between 2013 and 2014 in European countries with significant Roma populations. Its purpose was to better understand the expectations that motivate many governments in Europe to pilot or expand programmes to hire Roma staff into early childhood services as an explicit strategy to support Roma children and families (Klaus, 2014).

The survey sought a single response from an expert (who was knowledgeable about young Roma children and the early education system) in countries in the European Union, and countries seeking to become members, with estimated Roma populations of more than 100,000 and/or Roma populations forming more than 0.5 per cent of the total population. An initial draft questionnaire was pilot tested in two countries (Bosnia and Serbia) and revised to reduce both the scope of information sought as well as the depth of information collected. The final questionnaire contained 18 items, of which 12 were multiple choice or 'check all that apply', 4 required narrative responses, and 2 asked for statistics or identification of relevant reports. Responses were received from 24 experts in participating countries. A decision was taken to include narrative responses from all 24 surveys, as well as responses to questions asking about motivations for employing Roma in early education settings. For questions with more definitive answers, only one response was counted for each country. In three of the five cases where more than one survey was received (Albania, Czech Republic, Romania) the selection was easy, as one questionnaire from each country was substantially more fully completed than the others, demonstrating greater expertise. In the other two cases (UK and Greece) both respondents answered the policy questions similarly, triangulating, rather than confounding the data. Unfortunately, responses were not obtained from identified respondents in France, Germany and Portugal.

Data from the multiple-choice questions and quantitative responses (number of Roma employed) were entered into SPSS and analysed using basic descriptive statistics. As discussed above, for national policy questions only one response was coded per country, while all 24 responses were coded for multiple-choice questions asking about the motivations for employing Roma. Because the sample was so small, it was not possible to compare means of subgroups of respondents. The results provide insights into the extent of employment of Roma in general ECE systems, motivations 
for hiring Roma staff, perceived impacts of Roma staff and hiring trends (increasing, decreasing, stable, no trend).

The second study, Using Cultural Brokering Strategies to Improve the Early Education of Roma, Gypsy and Traveller Children: Case Studies from the UK and Serbia (Klaus, 2019), consists of two qualitative case studies conducted between 2015 and 2017, one in Serbia and the other in the UK, which focus on the cultural brokering strategies used in ECE settings to support Roma participation. The Serbian case study examines the impact of a national effort to hire Roma pedagogic assistants in preschools and primary schools, while the UK study explores the establishment of local authority services that perform a cultural brokering role, helping Gypsy, Roma and Traveller families in the UK to enrol children in education, and assist preschools and schools to gain competencies needed to support them. 'Gypsy' and 'Traveller' communities refers here to those who have lived in the UK for at least 500 years, while 'Roma' refers to the more recent influx of migrants from Europe from the mid-1990s onwards (Craig, 2011).

This article focuses on findings related to the Roma pedagogic assistants in Serbia and to the Roma teaching assistants in the UK. Key questions addressed in the study, adapted here to reflect the narrower focus of this article, include:

- Why were Roma assistants introduced in each country?

- What are the key features of this cultural brokering strategy in each system?

- What evidence is available to support the notion that hiring Roma assistants increases participation in, and quality of, ECE for Roma children?

- How do the people involved (teaching assistants, parents, teachers) perceive the impact of teacher assistants?

Evidence for the case studies was collected in two cities in each country from diverse sources, and included a review of relevant laws, documents and studies; interviews, focus groups and discussions with relevant stakeholders; classroom observations; and participation in relevant conferences (including a Serbian national conference on inclusive education, and a UK workshop for educators). Interviews and focus groups conducted across the two countries recorded the perspectives of 57 people, and observations were made in nine preschools and primary schools. Two UK local authority workers and four Serbian Pedagogic Assistants were shadowed to understand their roles. The study followed a parallel strategy in each country and similar strategies at each site: this ensured that the data were comparable.

Documents and reports were collected throughout the research period, and were read and annotated accordingly. Evidence was collected during field visits to the four cities in 2015. Interviews and focus groups were taped and transcribed, and those in Serbian were translated. Data processing included the production of memos documenting thoughts during the research process, observation notes, transcriptions of meetings and a review of documentary evidence. Analysis started with rereading all the transcriptions, memos, notes from observations and documentary evidence. It became possible to categorize information relating to the four research questions and to enter this on to Excel sheets. Further analysis and data reduction involved noting where there was triangulation of data and emerging explanatory patterns. The data and emerging patterns were then organized into a narrative case study for each country, capturing the dynamics of cultural brokering in each setting.

This study adheres to the ethical guidelines established by the British Educational Research Association (BERA, 2011) and was conducted following approval of the Research Ethics Committee of the UCL Institute of Education. Consent to research 
was obtained through local authorities and with the agreement of the preschools and schools that were visited. All participants completed consent forms. Additional measures were taken to communicate with, and protect the rights of, Roma participants. When conducting interviews or focus groups, and especially with Roma participants (some of whom do not have strong literacy skills) care was taken with the help of an interpreter to explain the aims and processes guiding the research project, participants' rights to withdraw at any time, and how information would be used, stored and erased. Interactions with Roma communities and parents were arranged and supervised by pedagogic assistants and Roma NGOs in Serbia and local authorities in the UK.

\section{Findings}

The results of the multi-country survey provide a framework to understand motivations and current trends in the hiring of Roma staff into ECE systems across Europe. This article then draws on the case studies from Serbia and the UK to illustrate similarities and differences in teacher assistant roles in two countries with regards to their creation and their key features. It also draws on evidence of impact, where this exists, and perceptions of key stakeholders.

\section{Roma teaching assistants across Europe: Evidence from the survey}

Evidence from the survey reveals that there appears to be a greater tendency to hire Roma in the Eastern European countries, with the largest numbers in Romania, Czech Republic and Serbia. Pilot programmes are being implemented in Ireland, Croatia, Macedonia and Kosovo, indicating growing interest. Few Roma are employed in preschools, with most in primary education systems.

The top motivations for creating Roma positions in preschools and primary schools are, unsurprisingly, to increase attendance, enrolment and educational outcomes. Yet a large number of respondents also cited improving communication and engagement of teachers and other school staff with Roma families. Roma staff also help to link Roma families with additional supports, most frequently with healthcare and social benefits, in addition to further education/training opportunities and parenting support, and, less frequently, with clothing, food coupons, housing, employment or legal advice. Few respondents cite provision of culturally relevant inputs to teachers or the school, and few recognize the potential positive impact on educational outcomes for all children. In assessing impacts on Roma children and families, respondents emphasize the positive impacts on children's cognitive and academic outcomes (improving attendance, learning, language attainment in both the majority and Roma languages), and their social-emotional development (providing role models, increasing self-confidence and identity of Roma children, while reducing discrimination).

Positive impacts on families are also observed. In the words of a UK respondent, 'Roma children and families communicate better with teaching/support staff via a Roma worker; expectations of the school regarding attendance, routines, behaviour can be clearly understood from the outset.' 'Roma families would feel more welcomed in the school', commented an Albanian respondent. And the respondent from Croatia elaborated, 'children and parents feel safer and less lost in the school environment.' Responses emphasize the crucial role that Roma staff have in building trust between the family, community and school. The Romanian respondent commented, 'for parents, it is highly important to have a relationship with the teachers and to be able to approach the person whom they trust with their children's education.' 
A number of comments refer to the role that Roma staff play in reducing discrimination. As the Serbian participant noted, 'they are advocates for the rights of Roma children.' Perceived impacts on majority (non-Roma) children include Roma staff's potential to improve attitudes and social cohesion by serving as role models, overcoming stereotypes, improving integration and helping the majority population to value diversity. Roma staff can 'overcome prejudices that non-Roma might have towards Roma', commented the Macedonian respondent. They can 'increase respect and understanding for all children and families irrespective of their background', noted the Swedish respondent. Fewer respondents commented on pedagogic benefits to non-Roma/majority children, although the respondent from Romania emphasized the mutual benefits of 'an increased awareness of the advantage of learning in a multicultural environment, and enriched interactions and learning situations.'

The practice of hiring Roma in preschools appears to have strong support across Europe. All respondents, with the exception of one who indicated uncertainty, agreed that having more Roma educators in preschools would improve Roma children's transition into formal (primary) education. In the next section, this article probes deeper into the evolution, roles and impact of Roma assistants in ECE, presenting evidence from the two case studies in Serbia and the UK.

\section{Roma pedagogic assistants in Serbia}

The hiring and deployment of Roma teacher assistants, known as pedagogic assistants in Serbia, was first piloted by the Open Society Foundations and the Centre for Interactive Pedagogy (CIP) in preschools in 1998 and in primary schools in 2002, as part of a comprehensive programme to introduce new models of child-centred, community-based education, and, by 2005, a number of organizations had begun to adopt the practice.

The Serbian government must implement anti-discrimination laws, and improve conditions for the Roma population, to qualify for accession to the European Union; this has created significant pressure to adopt legislation prohibiting discrimination, and to enact substantial education reforms. Beginning in 2006, the Ministry of Education, Science and Technology (MoEST) and the Organization for Security and Co-operation in Europe (OSCE) jointly implemented a formal pilot to test the benefits of employing Roma pedagogic assistants in 54 schools with high numbers of Roma pupils. Their job description includes: helping children to learn and continue education, supporting schools in developing an inclusive learning environment, empowering Roma families and mediating in the collaboration between Roma families and communities, and collaboration with local communities (Duvnjak et al., 2010).

The position of pedagogic assistants was formalized in 2009, and, since then, they have been hired directly by the Serbian government and matched to schools through a competitive process. Training consists of six classes provided by a national pedagogic institution in Kragujevac, with additional trainings provided periodically by the MoEST. In the 2015/16 academic year, there were 175 assistants (101 women and 74 men) distributed across Serbia, with around 25 per cent allocated to ECE and the rest to primary schools. A national study commissioned by the Serbian government in 2015 describes the 'average' pedagogic assistant as working for five years in the position, aged 31-40 years old (collectively they range from 20 to 58 years old), with a high-school education. The majority speak Romanes and over half have completed tertiary education (Milivojevic, 2015).

Their responsibilities depend on negotiations that take place at preschool and school level, and there are huge individual differences across the group. Those placed 
in preschools generally spend most of their time working with families in communities, while those in primary schools spend most time working in classrooms. Common roles observed include: liaising between education institutions and families and communities; providing links to resources (for examples, books, soap, food, clothing) and services, such as social welfare departments; providing direct support to children in classrooms; setting up supplementary parenting programmes; and serving as role models and change agents. In the words of one assistant:

We have always been advocating for democracy alongside this job. The real thing for the Roma community is to unite, to stay, and that's the only way to get more rights, to advocate more for our identity, culture, language, everything. And I can say that was the crucial thing why I got into this line of work.

Pedagogic assistants face challenges. Without adequate assistants available to support children with disabilities, Roma pedagogic assistants often end up taking on this responsibility. Significantly, they have neither job security nor career progression. It has been announced that reforms intended to bring more efficiency to the education system will lead to a reduction in the number of employees, and as recently as the 2014/15 school year, teachers went on strike to protest salary reductions. Although a number of assistants have the qualifications to become teachers, the economic context and political pressure from current teachers to protect their positions means, effectively, that these opportunities will not be forthcoming. For these reasons, pedagogic assistants formed an association in 2015. Their president commented:

We want to put the status of the pedagogic assistants to a higher level as an educational profession that has an important role in the education system ... We want to protect our rights because a number of our colleagues are victims of discrimination on their jobs.

There is ample evidence that Roma pedagogic assistants both increase participation in, and improve the quality of, ECE in Serbia. Evaluations have found positive impacts on academic achievement, attendance, Roma participation in extra-curricular activities, communication with parents, parent involvement, social cohesion and school climate, and access to and quality of education (Battaglia and Ledinski, 2015; Duvnjak et al., 2010; Friedman et al., 2015; Institute for the Evaluation of Education Quality, 2009). Pedagogic assistants caution that it is important that they not relieve teachers of the responsibility of building relationships with Roma children and families. One Roma pedagogic assistant clarified that she accepts requests from teachers struggling to communicate with the poorest families living in remote communities, who do not have phones and are difficult to find; however, she pushes teachers to make direct contact with those families that are easier to reach.

Qualitative data collected for this study reinforces the overwhelmingly positive impact of pedagogic assistants. As one local education authority official put it, 'I think that the pedagogic assistants did the most for the children to be enrolled in preschool. The results, the number of enrolled kids wouldn't be so good if they didn't join in.' Parents expressed relief at the opportunity to communicate with someone from their community: 'It's better when it is one of our own'. They are thankful for the support. There is demand for more pedagogic assistants. 


\section{Roma teaching assistants in the UK}

If the employment of pedagogic assistants on a national scale is driven in Serbia by the government's desire to join the European Union, the hiring of Roma teaching assistants in the UK is driven by preschools and schools that need to communicate with their Roma parents. The two cities visited during this study were coping with large influxes of Roma migrants in the past 10-15 years. In both cities, municipal services designed to serve several hundred Gypsy and Traveller children were challenged to reorganize to serve several thousand Roma migrant children with meagre additional resources. Like their Gypsy and Traveller counterparts, Roma children face discrimination; however, they are also faced with the daunting task of relocating to a new country, learning English, and adapting to a new culture and education system. Many come from remote rural towns and do not understand city life.

Both cities visited had invested in training and hiring Roma para-professional teaching staff. In one case, this took the form of a two-year pilot that supported 30 schools (infant, primary and secondary) to develop their practice. To address immediate needs, schools had begun hiring young Roma people and taking them off the streets. Although they had low levels of literacy, they were effective at communicating in their home language, and were much needed. It was a real learning experience, and one that reinforced the necessity of paying close attention to cultural and social issues.

Following the two-year pilot, the UK local authority then ran a programme of strategic overstaffing of Roma teaching assistants. They gave schools funds to recruit a cohort of young Roma, and then worked with them to provide training. Initially, select schools served as training sites, loaning Roma teaching assistants to other schools with the idea that, eventually, some schools would hire them. The local authority provided training - 14 half-day sessions - and placements for three cohorts of 14 Roma teaching assistants (a total of 42) over a six-month period. The training topics included an introduction to the UK education system, safeguarding children, language development, storytelling, using books, basic English as an additional language (EAL), importance of home language, early phonics concepts and basic early maths. They were also trained to work with parents, including how to enrol children into school.

An early years expert involved in the project noted that although the school's needs are met through hiring Roma teaching assistants, these systems can exploit them. 'They have just enough information to survive', she observed, yet few would like to take on further education and the successful ones often move on to higher paying jobs.

Staff from several schools noted how much parents used and valued the Roma teaching assistants. Around half their time is spent communicating with parents and half in classrooms with children. The Roma teaching assistants observed in classrooms were seen to be doing an excellent job co-teaching activities using both Romany and English language. A 2014 Ofsted report noted that bilingual teaching assistants are effective in improving home and school links. Yet they raised concerns that they are less effective when they are not fully fluent in English and are working in classrooms to support children where English is not their first language (Ofsted, 2014). Though nearly all Roma children participate in primary education in the UK, and these children make progress, Roma attain a fraction of the UK averages in reading, writing and maths. Social and economic factors outside the education system clearly play a decisive role for these children, creating a very large developmental gap before children enter school. 


\section{Discussion}

Evidence supports the importance of ensuring that both the curriculum and the transmission of learning are culturally relevant and meaningful to children - and that children can experience continuity across the very different environments in which they develop. Moreover, there is evidence from recent household surveys of the Roma community that parents would be more likely to send their children to preschool if there was a Roma person employed there. Estimates gleaned from the survey establish, conservatively, that Europe would need to employ eight to ten times more Roma $(40,000+$ additional staff) in ECE in order to achieve a teaching force that reflects the potential student body. Exercises like this estimate the scale of Europe's challenge.

The survey also identified two factors that influence the size of the Roma ECE workforce. First, Roma themselves may not be interested in becoming educators, or may not have the necessary qualifications; second, government policy impacts staffing composition. Therefore, a serious effort to increase the number of Roma staff in the ECE teaching force would need to concentrate on motivating young Roma to enter the education profession, on removing any barriers to their education and training, and on changing national policy - as Serbia has done - to create incentives or initiatives that encourage hiring Roma into education systems. It should be noted that there are legitimate concerns that creating Roma mediator or assistant positions, rather than recruiting qualified Roma into full teaching positions, will lead to further discrimination of Roma as lower qualified, lower status education staff. One recent positive development has been the launch of the Roma Early Years Network (REYN) established by the International Step by Step Association in collaboration with the Open Society Foundations to support practitioners working with Roma children. REYN is a pan-European network with a growing number of associated national networks, which gives new visibility and status to Roma professionals and paraprofessionals in early years services to motivate young Roma to enter and progress in the early education profession.

There are several striking differences between the Roma pedagogic assistants in Serbia and the UK. In Serbia, they are better educated, better trained and better networked: their training and roles are defined nationally and most stay in their positions. In contrast, they are generally hired in an ad-hoc manner by UK preschools (though, in some cases, municipalities have promoted the practice), they receive minimal training and professional development and few, if any, opportunities to network. As a result, few remain in their positions or advance, even though additional support for Roma children is clearly needed. These kinds of discrepancies illustrate the importance of providing clearer explanations of the important role that cultural brokers, such as Roma teaching assistants, play in ECE, and using this to promote their thoughtful and intentional employment in ECE systems.

Although teaching assistants are having a robust impact on Roma children's participation in ECE in both Serbia and the UK, there are significant gaps in attainment and outcomes. Research speaks to the imperative of providing earlier, more intensive and comprehensive interventions with disadvantaged families and young children, like the Roma families and children who are the focus of these studies. In fact, overfocusing on universal preschool education at the expense of implementing more holistic programmes for the most disadvantaged children may be detrimental. A review of ten of the most prominent early childhood programmes in the United States demonstrated that the most promising effects emerge from well-designed, holistic early childhood development programmes, high-quality childcare and home- 
visiting programmes that go beyond supporting children's learning to enable parents' employment and build parenting skills (Stevens and English, 2016). The first thousand days after conception are recognized as a sensitive period during which children's development is vulnerable to adversity and responsive to supportive environments because the brain develops most rapidly during this period (Black et al., 2017). Studies that have explored why some children of low socio-economic status, such as Roma children, in the UK succeed against the odds, point to a range of factors. These include the quality of home learning environment, children's and parents' motivation and determination, and parenting styles. The quality of relationships with parents, teachers and peers appears to serve as a protective factor for these disadvantaged children, and supportive learning environments (formal and informal) outside the home also play a role (Siraj and Mayo, 2014). One could argue that these relationships and opportunities represent social capital that these families are able to build - despite their low incomes. More comprehensive and earlier programming for vulnerable children, such as the Roma children in this study, is needed.

Finally, poverty, discrimination, migration status and socio-economic status play a definitive role in the lives of Roma, yet education systems have few mechanisms through which they can address these broader social issues. What is within their remit, however, is the potential to cooperate with these children and families in more effective ways, to eliminate any barriers and to welcome them into ECE settings. Cultural brokers, such as the teacher assistants discussed in this article, offer an effective beginning to approach these challenges (Weaver, 1971).

\section{Notes on the contributors}

Sarah Klaus leads a team of specialists who develop and implement the Open Society Foundation's global early childhood portfolio. The programme improves services and policies that impact young children, particularly minority and disadvantaged groups, including Roma, and builds capacity of early childhood professionals. In 1994, Klaus helped launch Step by Step, the Foundations' flagship early childhood programme, and in 1999, the International Step by Step Association, a network established to support early childhood professionals in Europe and Eurasia.

Iram Siraj is Professor of Child Development and Education, Department of Education, University of Oxford. Her research focuses on understanding the relationship between quality, pedagogy and early assessment on young children's developmental outcomes. She works in transdisciplinary teams on longitudinal studies to assess the long-term impact of the quality of preschool and home environments on children from differing backgrounds, especially those who are vulnerable.

\section{References}

Battaglia, M. and Lebedinski, L. (2015) 'Equal access to education: An evaluation of the Roma Teaching Assistant Program in Serbia'. World Development, 76, 62-81.

Bennett, J. (2012) Roma Early Childhood Inclusion: The RECl overview report. London: Open Society Foundations. Online. https://tinyurl.com/vg7umqz (accessed 15 November 2019).

BERA (British Educational Research Association) (2011) Ethical Guidelines for Education Research. Rev. ed. London: British Educational Research Association.

Black, M.M., Walker, S.P., Fernald, L.C.H., Andersen, C.T., DiGirolamo, A.M., Lu, C., McCoy, D.C., Fink, G., Shawar, Y.R., Shiffman, J., Devercelli, A.E., Wodon, Q.T., Vargas-Barón, E. and GranthamMcGregor, S. (2017) 'Early childhood development coming of age: Science through the life course'. The Lancet, 389 (10064), 77-90. 
Brüggemann, C. (2012) Roma Education in Comparative Perspective: Findings from the UNDP/World Bank/EC Regional Roma Survey (Roma Inclusion Working Papers). Bratislava: United Nations Development Programme. Online. https://tinyurl.com/ldhvuca (accessed 15 November 2019).

Chireac, S.-M. and Arbona, A.D. (2016) 'Improving and protecting human rights: A reflection of the quality of education for migrant and marginalized Roma children in Europe'. Regions and Cohesion, 6 (3), 52-76.

CoE (Council of Europe) (2012) 'Estimates on Roma population in European countries'. Online. https://tinyurl.com/yfrs4uy4 (accessed 18 December 2019).

Craig, G. (2011) United Kingdom: The Roma: A study of national policies. Brussels: European Commission. Online. www.york.ac.uk/inst/spru/research/pdf/EURoma.pdf (accessed 15 November 2019).

Demeuse, M., Frandji, D., Greger, D. and Rochex, J.-Y. (eds) (2012) Educational Policies and Inequalities in Europe. Basingstoke: Palgrave Macmillan.

Duvnjak, N., Mihajlovic, M., Skarep, A., Stojanovic, J. and Trikic, Z. (2010) Roma Pedagogic Assistants as Agents of Change: The importance and meaning of their role, fields of activity and influence on the changes in schools and in the Roma community. Trans. Bajic, J. Belgrade: OSCE Mission to Serbia.

European Commission (2011) 'An EU framework for national Roma integration strategies up to 2020 (COM(2011) 173)'. Online. https://tinyurl.com/y9es9cst (accessed 27 November 2019).

European Commission (2013a) Barcelona Objectives: The development of childcare facilities for young children in Europe with a view to sustainable and inclusive growth. Luxembourg: Publications Office of the European Union.

European Commission (2013b) 'Commission recommendation of 20 February 2013 - Investing in children: Breaking the cycle of disadvantage (2013/112/EU)'. Official Journal of the European Union, L 59/5. Online. https://tinyurl.com/rsynmqn (accessed 27 November 2019).

FRA (European Union Agency for Fundamental Rights) (2016) Second European Union Minorities and Discrimination Survey: Roma - selected findings. Luxembourg: Publications Office of the European Union. Online. https://tinyurl.com/t7pqncs (accessed 27 November 2019).

FRA (European Union Agency for Fundamental Rights) and UNDP (United Nations Development Programme) (2012) The Situation of Roma in 11 EU Member States: Survey results at a glance. Luxembourg: Publications Office of the European Union. Online. https://tinyurl.com/rw37p9f (accessed 27 November 2019).

Friedman, E., Pavlović Babić, D. and Simić, N. (2015) Inclusive Education in Serbia: Policies, practice and recommendations. Belgrade: World Bank Group.

Fundación Secretariado Gitano (2009) Health and the Roma Community: Analysis of the situation in Europe: Final report. Madrid: Fundación Secretariado Gitano. Online. www.gitanos.org/upload/07/81/memoria_gral_fin.pdf (accessed 27 November 2019).

Heckman, J.J., Moon, S.H., Pinto, R., Savelyev, P.A. and Yavitz, A. (2010) 'The rate of return to the HighScope Perry Preschool Program'. Journal of Public Economics, 94 (1-2), 114-28.

Institute for the Evaluation of Education Quality (2009) Evaluation Study: The role of pedagogical assistants for the support of Roma students as a systemic measure for improving the education of Roma. Belgrade: Institute for Evaluation of Education Quality.

Irwin, L.G., Siddiqi, A. and Hertzman, C. (2007) Early Childhood Development: A powerful equalizer. Vancouver: Human Early Learning Partnership.

Jezewski, M.A. (1995) 'Evolution of a grounded theory: Conflict resolution through culture brokering'. Advances in Nursing Science, 17 (3), 14-30.

Klaus, S. (2014) 'Straggling Behind: Participation of Roma children and employment of Roma staff in early childhood education in Europe'. EdD thesis, UCL Institute of Education.

Klaus, S. (2019) 'Using Cultural Brokering Strategies to Improve the Early Childhood Education of Roma, Gypsy and Traveller Children: Case studies from the UK and Serbia'. Unpublished EdD thesis, University College London.

La Paro, K.M. and Pianta, R.C. (2000) 'Predicting children's competence in the early school years: A meta-analytic review'. Review of Educational Research, 70 (4), 443-84.

Liégeois, J.-P. (2013) Developments in Mediation, Current Challenges and the Role of ROMED: Training programme for Roma mediators. Strasbourg: Council of Europe Publishing.

Marmot, M. (2010) Fair Society, Healthy Lives: The Marmot Review executive summary: Strategic review of health inequalities in England post-2010. London: Marmot Review. Online. https://tinyurl.com/y76mb5q2 (accessed 27 November 2019).

Martinez-Cosio, M. and lannacone, R.M. (2007) 'The tenuous role of institutional agents: Parent liaisons as cultural brokers'. Education and Urban Society, 39 (3), 349-69. 
Milivojevic, Z. (2015) 'Analysis of the legal framework, status and practice of pedagogic assistants'. Belgrade. Online. https://tinyurl.com/uyoyewg (accessed 27 November 2019).

Ofsted (Office for Standards in Education, Children's Services and Skills) (2014) Overcoming Barriers: Ensuring that Roma children are fully engaged and achieving in education. Manchester: Ofsted.

Peeters, J., Sharmahd, N. and Budginaite, I. (2016) Professionalisation of Childcare Assistants in Early Childhood Education and Care (ECEC): Pathways towards qualification. NESET II report. Luxembourg: Publications Office of the European Union. Online. https://tinyurl.com/ufjnhnf (accessed 27 November 2019).

Peeters, J., Sharmahd, N. and Budginaité, I. (2018) 'Early childhood education and care (ECEC) assistants in Europe: Pathways towards continuous professional development (CPD) and qualification'. European Journal of Education, 53 (1), 46-57.

Phillips, D. and Crowell, N.A. (eds) (1994) Cultural Diversity and Early Education: Report of a workshop. Washington, DC: National Academy Press.

Putnam, R.D. (2000) Bowling Alone: The collapse and revival of American community. New York: Simon and Schuster.

Rus, C. (2006) The Situation of Roma School Mediators and Assistants in Europe (DGIV/EDU/ ROM(2006)3). Strasbourg: Council of Europe. Online. https://tinyurl.com/sr27jcn (accessed 27 November 2019).

Schweinhart, L.J., Montie, J., Xiang, Z., Barnett, W.S., Belfield, C.R. and Nores, M. (2005) The High/ Scope Perry Preschool Study through Age 40: Summary, conclusions, and frequently asked questions. Ypsilanti, MI: High/Scope Press. Online. https://tinyurl.com/yd7qv433 (accessed 27 November 2019).

Siraj, I. and Mayo, A. (2014) Social Class and Educational Inequality: The impact of parents and schools. Cambridge: Cambridge University Press.

Stevens, K.B. and English, E. (2016) Does Pre-K Work? The research on ten early childhood programs - and what it tells us. Washington, DC: American Enterprise Institute. Online. https://tinyurl.com/jmuv7np (accessed 27 November 2019).

Sylva, K., Melhuish, E., Sammons, P., Siraj-Blatchford, I. and Taggart, B. (2008) Effective Pre-school and Primary Education 3-11 Project (EPPE 3-11): Final report from the primary phase: Pre-school, school and family influences on children's development during Key Stage 2 (age 7-11) (Research Report DCSF-RR061). Nottingham: Department for Children, Schools and Families. Online. https://tinyurl.com/srjvw58 (accessed 27 November 2019).

Sylva, K., Melhuish, E., Sammons, P., Siraj-Blatchford, I. and Taggart, B. (2010) Early Childhood Matters: Evidence from the Effective Pre-school and Primary Education project. London: Routledge.

UNESCO and CoE (United Nations Educational, Scientific and Cultural Organization and Council of Europe) (2014) Inclusion from the Start: Guidelines on inclusive early childhood care and education for Roma children. Paris: United Nations Educational, Scientific and Cultural Organization. Online. https://tinyurl.com/lcvsvnk (accessed 27 November 2019).

Vančíková, K., Balážová, Z., Kosová, I., Vaněk, B. and Rafael, V. (2017) Roma Early Childhood Inclusion+: Special report on Roma inclusion in early childhood education and care: Slovak Republic. London: Open Society Foundations.

Weaver, K.D. (1971) Lenin's Grandchildren: Preschool education in the Soviet Union. New York: Simon and Schuster.

World Bank (2012) Toward an Equal Start: Closing the early learning gap for Roma children in Eastern Europe. Washington, DC: World Bank. Online. https://tinyurl.com/seylz9r (accessed 27 November 2019).

Wyatt, J.D. (1978) 'Native involvement in curriculum development: The native teacher as cultural broker'. Interchange, 9 (1), 17-28. 